Profesor dr Milojko Jevtović, dipl. inž.

Elektrotehnički fakultet,

Banja Luka

\section{PRESLIKAVANJE PARAMETARA KVALITETA USLUGA NA PROTOKOLE ATM MREŽA}

UDC: 004.738

Rezime:

Preslikavanje parametara kvaliteta usluga (Quality of Service - QoS) jedan je od bitnih elemenata u koncepciji ATM (Asynchronous Transfer Mode) širokopojasnih mreža. U radu su opisani parametri QoS-a (verovatnoće pogrešnih ramova i ćelija, propusni opseg, kašnjenje ćelija, varijacija kašnjenja) koji se preslikavaju na protokole ATM mreža. Preslikavanje se izvodi između korisničkog $i$ aplikacionog QoS-a, a aplikacioni QoS se preslikava na QoS prenosa $i$ komutacije, odnosno na ATM protokole, tzv. protokole ATM adaptacionog sloja i, konačno, preslikava se (mapira) na ATM mrežne performanse (ATM sloj). Analiza procesa preslikavanja parametara kvaliteta usluga značajna je sa stanovišta korisnika usluga ATM mreža pri izboru klasa usluga koje će koristiti u komunikaciji preko date ATM mreže.

Ključne reči: kvalitet usluga (QoS), preslikavanje, asinhroni način transfera (ATM), protokoli, ATM telekomunikacione mreže, QoS parametri, protokoli ATM-a.

\title{
QUALITY OF SERVICE MAPPING TO ATM NETWORK PROTOCOLS
}

Summary:

Quality of service mapping is one of the crucial elements in ATM concept of wide networks. In this paper QoS parameters mapping to ATM network protocols are described. Mapping is made between $Q O S$ user and $Q o S$ application, and application $Q o S$ is mapped to QoS transfer and commutation i.e. to ATM protocols - ATM adaptation layer protocols and finally it is mapped to ATM network performances. Analysis of this QoS mapping parameters process is very important for ATM users when they are choosing classes of service that can be used in communication process through ATM network.

Key words: Quality of Service (QoS), mapping, Asynchronous Transfer Mode (ATM), protocols, ATM communication networks, QoS parameters, ATM protocols.

\section{Uvod}

Telekomunikacione širokopojasne ATM (Asynchronous Transfer Mode) mreže realizuju se radi obezbeđenja istovremenog prenosa govornih, video $i$ audio signala, tekstualnih i grafičkih poruka, mirne slike i podataka, odnosno da obezbede prenos multimedijalnih poruka. Za svaki pomenuti tip poruka od ATM mreže zahteva se određeni nivo kvaliteta usluga (Quality of Service - QoS). Multimedijal- na komunikacija nametnula je potrebu za uvođenjem zahteva za kvalitet usluga [1]. Kvalitet usluga definisan je za digitalne telekomunikacije ITU-T preporukom I.350. Ovom preporukom - standardom, QoS se definiše kao združeni efekat performansi usluge koji određuje nivo zadovoljstva korisnika datom uslugom. S obzirom na to da je zadovoljstvo korisnika uslugom subjektivna veličina, potrebno je da se utvrde objektivni parametri. Ti parametri kvaliteta su kvantitativne veličine, a 
mogu se neposredno meriti u tački u kojoj korisnik direktno pristupa usluzi [2].

Tehnika asinhronog načina prenosa (ATM), primenjena pri multipleksiranju, prenosu i komutaciji, omogućila je da se formiraju širokopojasne telekomunikacione mreže sa novom mrežnom arhitekturom i mogućnostima realizacije novih mrežnih usluga, uključujući multimedijalnu komunikaciju.

\section{Arhitektura ATM protokola}

Arhitektura ATM protokola, sa detaljnije predstavljenim protokolima ATM adaptacionog sloja, prikazana je na slici 1 .
Funkcija fizičkog sloja jeste da omogući prenos signala, tj. ATM ćelija, preko medijuma prenosa (metalni kabl, optički kabl, radio-relejni linkovi).

ATM sloj ili protokol sadrži identifikatore virtuelnih kanala (VCI) i virtuelnih puteva (VPI), omogućava prenos, generisanje i izdvajanje zaglavlja ćelije, kao i multipleksiranje i demultipleksiranje ćelija sa različitim VPI/VCI [1].

ATM adaptacioni sloj (AAL sloj) namenjen je za realizaciju različitih usluga, prilagođavajući format korisničkih informacija strukturi ćelije. Sloj ALL sadrži više tipova protokola koji podržavaju određene klase usluga.

\begin{tabular}{|c|c|c|c|c|c|c|c|}
\hline \multirow{2}{*}{$\begin{array}{l}\text { SVC CLASS } \\
\text { ( SVC KLASA) }\end{array}$} & A & B & C &.$Y^{\prime \prime}$ & N/A & "x" $x^{\prime \prime}$ & $D$ \\
\hline & $\begin{array}{l}\text { CONSTANT } \\
\text { BIT RATE }\end{array}$ & \multicolumn{6}{|c|}{ YARLABLE BIT RATE (promenljiva bitska brzina) } \\
\hline \multirow{2}{*}{$\begin{array}{l}\text { PARAMETERS } \\
\text { ( PMAMEMRA) }\end{array}$} & \multicolumn{6}{|c|}{ CONNECTION ORIENTED ( ORIMENTISANI VEZAMA) } & Codn \\
\hline & \multicolumn{2}{|c|}{ TIMING PRESERVED } & \multicolumn{4}{|c|}{ VARIABLE DALAY ACCEPTABLE } & \\
\hline $\begin{array}{c}\text { HWGHER } \\
\text { LAUER } \\
\text { ( VISI SLOJEVI) }\end{array}$ & \begin{tabular}{|c|} 
ANY \\
( bilo koji )
\end{tabular} & $\begin{array}{c}\text { ANY } \\
\text { (bilo koji) }\end{array}$ & $\begin{array}{l}\text { FRAME } \\
\text { RELAY } \\
\text { TCP/IP } \\
\end{array}$ & $\begin{array}{c}\text { ANY } \\
\text { (bib koji) }\end{array}$ & $\left(\begin{array}{l}02931 \\
(093)\end{array}\right.$ & N/A & $\begin{array}{l}\text { SIP-3 } \\
\text { OTHERS }\end{array}$ \\
\hline $\begin{array}{l}\text { TYFICAL } \\
\text { USE } \\
\text { ( IIPICNE PRIM.) }\end{array}$ & \multirow{2}{*}{$\begin{array}{l}\text { CIRCUIT } \\
\text { BMUATION } \\
\text { ( EMUACANA } \\
\text { KOA) } \\
\text { 1 BIT } \\
\text { (SRIS) }\end{array}$} & \multirow{2}{*}{\begin{tabular}{|l|} 
YBR VOICE \\
YIDEO \\
( GOYOR \\
YIDEO) \\
IBD
\end{tabular}} & \multirow{2}{*}{$\begin{array}{l}\text { CONN OR } \\
\text { DATA } \\
\text { (PODACI) } \\
\text { FR.SSCS } \\
\end{array}$} & \multirow{2}{*}{$\begin{array}{l}\text { AVAIL } \\
\text { BIT RATE } \\
\text { IBD }\end{array}$} & \multirow{2}{*}{$\begin{array}{l}\text { SIGNALING } \\
\text { ( SIGALLIZAC) } \\
\text { SSCOP } \\
\text { (SAAL) }\end{array}$} & \multirow{2}{*}{$\begin{array}{c}\text { CEUL RELAY } \\
\text { NULL }\end{array}$} & \multirow{2}{*}{\begin{tabular}{|c|} 
CONN \\
LESS DARA \\
CLNS \\
$($ SIP 3$)$ \\
\end{tabular}} \\
\hline$A^{\operatorname{sscs}}$ & & & & & & & \\
\hline $\operatorname{cocs}$ & Aal-1 & $A A L-2$ & & $A A L-5$ & & Whe & $A A L-3 / 4$ \\
\hline $\begin{array}{c}\text { OVEAHEAD } \\
\text { (PFEMASENE) } \\
\text { SAR } \\
\text { PAILOAD }\end{array}$ & $\begin{array}{l}1 \text { BYTE } \\
47 \text { BYTES }\end{array}$ & $\begin{array}{c}\text { 1-3 BYTES } \\
\text { (PRELIM) } \\
45-47 \text { BYTES }\end{array}$ & $\begin{array}{l}8 \text { BYTES } \\
+ \text { PAD } \\
\text { N.48 } \\
48 \text { BYTES }\end{array}$ & IBD & $\begin{array}{l}8 \text { BYTES } \\
+ \text { PAD } \\
\text { N.48 } \\
48 \text { BYTES } \\
\end{array}$ & NONE & $\begin{array}{l}4 \text { BYTES } \\
+03 \text { PAD } \\
44 \text { BYTES }\end{array}$ \\
\hline \multirow[t]{2}{*}{ ( KOFISNA WFOR } & \multicolumn{7}{|c|}{ ATM LAYER ( ATM SLOJ) } \\
\hline & \multicolumn{7}{|c|}{ PHYSICAL LAYER ( FIZIČKI SLOJ) } \\
\hline \multicolumn{8}{|c|}{$\begin{array}{l}\text { Sl. } 1 \text { - Arhitektura ATM protokola (AAL sloj): } \\
\text { AAL-ATM adaptacioni sloj (ATM Adaptation Layer); A, B, C, D-klase usluga definisane ITU-T;,,X“,,Y“-klase } \\
\text { usluga pri promenljivoj bitskoj brzini; ,,N/A“-klase usluga koje se odnose na signalizaciju AAL; SVC-komutirani- } \\
\text { virtuelni kanali ili komutirana virtuelna kola; SVC class - SVC klase usluga; VBR - promenljiva bitska brzina } \\
\text { (Variable Bit Rate); SSCS - podsloj specifične usluge (Service Specific Convergence Sublayer); SAR - segmentacija i } \\
\text { reasembliranje (Segmentation and Reassembly); TCP/IP - protokol upravljanja prenosom/međumrežni protokol } \\
\text { (Transmission Control Protocol/Internet); CLNS - mrežne usluge (Connection less network services) }\end{array}$} \\
\hline
\end{tabular}


Protokol AAL-1 koristi se za prenos signala primarnog multipleksa E1 i T1.

Protokol AAL-2 razvijen je za prenos signala sa promenljivom bitskom brzinom, kao što su signali multimedijalnih poruka, prenos komprimovanih video i audio signala, pri čemu se koriste različite tehnike kompresije.

Protokol AAL-3/4 namenjen je za prenos podataka po uspostavljenoj vezi. AAL-3/4 podržava različite protokole, uključujući TCP/IP komplet protokola.

Protokol AAL-4 primenjuje se za prenos podataka bez prethodne uspostave veze.

Protokol AAL-5 opisuje se kao jednostavan i efikasan protokol za prenos podataka po uspostavljenoj vezi.

Za razliku od drugih telekomunikacionih mreža, širokopojasne ATM mreže omogućavaju garantovani kvalitet usluga pri prenosu multimedijalnih poruka. Kod ATM mreža QoS se definiše kao tehnika koja se odnosi na skup parametara za opisivanje ATM karakteristika, koje karakterišu saobraćaj na datom virtuelnom putu ATM mreže. U ovom slučaju parametre kvaliteta čine: verovatnoća gubitka ćelije, broj pogrešno prenetih ćelija, verovatnoća pojave pogrešno ubačenih ćelija, kašnjenje ćelija u prenosu, varijacija kašnjenja ćelija i verovatnoća bitske greške.

\section{Karakteristike ATM saobraćaja}

ATM saobraćaj čini protok ćelija kroz telekomunikacionu mrežu. Krajnje odredište ćelije navedeno je u njenom zaglavlju. To zaglavlje analizira se u svakom ATM čvoru mreže, a ćelija se usmerava u toku prenosa preko virtuelnih kanala, koji defi- nišu put poruke od izvora do odredišta. ATM veze ne zahtevaju striktno definisan kanal već je konkretna ATM veza podržana određenim kapacitetom kanala koji je potreban u datom momentu [3].

ATM mreža dodeljuje korisniku propusni opseg za različite bitske protoke, odnosno onaj propusni opseg koji se korisniku (u zahtevanom trenutku) može staviti na raspolaganje.

Zahtev za novu vezu mreža prihvata se samo ukoliko traženi kvalitet usluge može biti osiguran, a kvalitet ranije uspostavljenih veza očuvan, $\mathrm{tj}$. bez narušavanja ugovorenog kvaliteta sa drugim korisnicima.

\section{Kašnjenje signala}

Klasične digitalne mreže, zasnovane na komutaciji kola-kanala, pri prenosu govornih signala, unose kašnjenje reda $450 \mu$ s po jednom čvoru ili manje. Pri kašnjenju većem od $25 \mu$ s moraju se primenjivati tehnike poništavanja eha (odjeka). Kašnjenje veće od $75 \mu$ s primetno je za učesnike u razgovoru. Kašnjenja govornih signala veća od $200 \mu$ s unose znatno smanjenje kvaliteta govora pri prenosu, a ako su veća od $450 \mu \mathrm{s}$, među sagovornicima dijalog nije moguć.

Kašnjenja u ATM mreži su reda 6 $\mu$ s za funkciju segmentacije i reasembliranja (Segmentation And Reasembling SAR), odnosno deljenje poruke na ćelije i ponovno sastavljanje celovite poruke. Ako se koriste postupci poništavanja varijacije kašnjenja signala, unosi se dodatno kašnjenje reda $2 \mu$ s. Takođe, kašnjenje unose i različiti medijumi prenosa ATM signala. 


\section{Zagušenje u ATM saobraćaju}

Problem zagušenja u saobraćaju nastaje kada je broj dolaznih ćelija veći od kapaciteta bafera određenog komutacionog čvora ili prenosnog puta između čvorova. Formiraju se redovi čekanja, čime se unosi kašnjenje u prenosu. Problem je kako izbeći prepunjavanje redova čekanja u pristupu baferima komutacionih čvorova, onda kada protok premaši kapacitet raspoloživih kanala.

Jedan od načina rešavanja problema zagušenja jeste da se izvrši korektno dimenzioniranje kapaciteta bafera u komutacionim čvorovima. Takođe, rešenje je $u$ kontroli i upravljanju saobraćajem, primenom mera kao što su: upravljanje pristupom mreži, oblikovanje saobraćaja, nadgledanje saobraćaja u čvorovima i kontrola zagušenja.

\section{Brzine prenosa ATM signala}

Da bi se podržale različite korisničke potrebe i zadovoljile nove komunikacione usluge, a u prvom redu multimedijalna komunikacija, ATM mreža treba da omogući prenos poruka različitim bitskim brzinama, odnosno protocima, kao što su:

- konstantan bitski protok CBR (Constant Bit Rate),

- promenljivi bitski protok VBR (Variable Bit Rate),

- raspoloživi bitski protok ABR (Avilable Bit Rate),

- neodređeni bitski protok UBR (Unspecified Bit Rate).

Svaka od navedenih bitskih brzina namenjena je za realizaciju različitih klasa usluga.

\section{Zahtevani kvalitet}

Osnovni parametri kvaliteta koje treba da obezbedi telekomunikaciona mreža, a koji se zahtevaju za prenos govora, video signala i podataka, prikazani su u tabeli 1.

Tabela 1

Zahtevani kvalitet u prenosu govora, video signala $i$ podataka

\begin{tabular}{|l|c|c|c|}
\hline \multicolumn{1}{|c|}{$\begin{array}{c}\text { Zahtevani } \\
\text { kvalitet }\end{array}$} & $\begin{array}{c}\text { Govorni } \\
\text { signali }\end{array}$ & $\begin{array}{c}\text { Video } \\
\text { signali }\end{array}$ & Podaci \\
\hline Propusni opseg & uzak & širok & varijabilan \\
\hline $\begin{array}{l}\text { Osetljivost na } \\
\text { kašnjenje }\end{array}$ & velika & srednja & varijabilna \\
\hline $\begin{array}{l}\text { Osetljivost na } \\
\text { greške }\end{array}$ & mala & $\begin{array}{c}\text { relativno } \\
\text { mala }\end{array}$ & velika \\
\hline $\begin{array}{l}\text { Usnopljenost } \\
\text { poruka u prenosu }\end{array}$ & ne postoji & ne postoji & velika \\
\hline
\end{tabular}

Pri prenosu govorni signal zahteva uzak propusni opseg, veoma je osetljiv na kašnjenje, nije osetljiv na bitske greške i prenosi se kontinualno.

Video signal u prenosu zahteva širok propusni opseg, umereno je osetljiv na kašnjenje, a osetljivost na greške mu je relativno mala.

Podaci za prenos zahtevaju varijabilan propusni opseg, osetljivost na kašnjenje je varijabilna, dok im je osetljivost na greške velika. Poseduju osobinu naletnosti, odnosno usnopljen karakter informacija pri prenosu.

Zahtevi za kvalitet prenosa signala preko ATM mreža definisani su standardima Međunarodne unije za telekomunikacije (ITU-T), koji se odnose na širokopojasne mreže [4].

Performanse ATM mreže karakterišu sledeći mrežni parametri kvaliteta:

- verovatnoća gubitka ćelija CLR (Cell Loss Ratio) - odnos broja izgubljenih prema zbiru broja izgubljenih i uspešno prenetih ćelija; 
- brzina ubacivanja ćelija CIRa (Cell Insertion Rate) - broj ubačenih ćelija (u nizu primljenih ćelija u posmatranom intervalu vremena) u jedinici vremena;

- verovatnoća ubacivanja ćelija CIR (Cell Insertion Ratio) - odnos broja ubačenih ćelija prema zbiru broja ubačenih i broja otpremljenih ćelija;

- verovatnoća prosečno pogrešnih ćelija SCR (Severely Cell Ratio) - odnos broja prosečno pogrešnih ćelija prema broju uspešno prenetih ćelija;

- kapacitet prenosa ćelija CTC (Cell Transfer Capacity) - maksimalan broj uspešno prenetih ćelija u jedinici vremena, na posmatranoj vezi;

- kašnjenje u prenosu ćelija CTD (Cell Transfer Delay) - aritmetička srednja vrednost kašnjenja određenog broja ćelija;

- varijacija kašnjenja ćelija CVD (Cell Variation Delay) - ukupno kašnjenje u prenosu i komutaciji između dva odredišta u mreži;

- verovatnoća bitske greške BER (Bit Error Rate) - odnos broja pogrešnih bita prema broju ukupno primljenih (prenetih) bita u posmatranom intervalu.

Svi navedeni parametri kvantitativno su definisani preporukama ITU-T.

\section{Preslikavanje QoS zahteva na ATM protokole}

Širokopojasne mreže od samog početka su osmišljene, definisane i projektovane tako da korisnicima omoguće različite usluge i zahteve za QoS u istoj ATM mreži. Tradicional- no, po prirodi poruka, prenos podataka, govornih i video signala zahteva različit QoS. ATM je razvijen s ciljem da podrži sva tri tipa saobraćaja u jednoj istoj mreži. Pored različite QoS podrške, ATM omogućava veoma dobru efikasnost u korišćenju raspoloživog kapaciteta kanala i obezbeđuje dobru procenu zahtevanog kapaciteta za svaku vrstu saobraćaja. Efikasno upravljanje kvalitetom usluga osnovna je prednost ATM tehnike prenosa, multipleksiranja i komutacije. Upravljanje QoS-om ostvaruje se primenom slojevite strukture ATM adaptacionih slojeva AAL (ATM Adaptation Layer), odnosno ATM protokola, upravljanjem pristupom i uobličavanjem ponuđenog saobraćaja.

U ATM mrežama QoS se obezbeđuje korišćenjem virtuelnih kanala (VC) i virtuelnih puteva (VP) koji se uspostavljaju sistemom signalizacije No 7 , pre početka prenosa poruka u formatu ćelija. Između izvora i odredišta uspostavlja se logička - virtuelna veza, preko koje se prenose sve ćelije koje pripadaju istoj poruci.

Pri uspostavi veze uzimaju se u obzir parametri kvaliteta koji se odnose na zahtevani QoS, odnosno komunikaciju u realnom vremenu. To se postiže preslikavanjem određenih klasa usluga - CoS (Class of Service) na AAL slojeve, odnosno ATM protokole.

U tabeli 2 prikazano je preslikavanje parametara QoS na odgovarajuće AAL slojeve. Za svaku klasu data su dva imena, koje je ranije definisao ITU-T i njihovi ekvivalenti koje je definisao ATM forum. 
Tabela 2 usluge, mora da poseduje niz funkcija,

Preslikavanje QoS na AAL protokole

\begin{tabular}{|c|c|c|c|c|c|}
\hline $\begin{array}{c}\text { ITU-T } \\
\text { ATM } \\
\text { forum }\end{array}$ & $\begin{array}{c}\text { Klasa A } \\
\text { CBR }\end{array}$ & $\begin{array}{c}\text { Klasa B } \\
\text { VRR (RT) }\end{array}$ & $\begin{array}{c}\text { Klasa C } \\
\text { VBR } \\
\text { (NRT) }\end{array}$ & $\begin{array}{c}\text { Klasa D } \\
\text { UBR }\end{array}$ & $\begin{array}{c}\text { Klasa Y } \\
\text { ABR }\end{array}$ \\
\hline $\begin{array}{c}\text { Bitska } \\
\text { brzina }\end{array}$ & konstantna & varijabilna & varijabilna & varijabilna & varijabilna \\
\hline $\begin{array}{c}\text { Sinhroni- } \\
\text { zacija; } \\
\text { vrem. } \\
\text { odnosi }\end{array}$ & zahteva se & zahteva se & $\begin{array}{c}\text { ne zahteva } \\
\text { se }\end{array}$ & $\begin{array}{c}\text { ne zahteva } \\
\text { se }\end{array}$ & $\begin{array}{c}\text { ne zahteva } \\
\text { se }\end{array}$ \\
\hline $\begin{array}{c}\text { Tip } \\
\text { veze }\end{array}$ & $\begin{array}{c}\text { konekciono } \\
\text { orijentisana }\end{array}$ & $\begin{array}{c}\text { konekciono } \\
\text { orijentisana }\end{array}$ & $\begin{array}{c}\text { konekciono } \\
\text { orijentisana }\end{array}$ & $\begin{array}{c}\text { bez } \\
\text { uspostave } \\
\text { veze }\end{array}$ & $\begin{array}{c}\text { bez } \\
\text { uspostave } \\
\text { veze }\end{array}$ \\
\hline $\begin{array}{c}\text { Garancija } \\
\text { QoS }\end{array}$ & $\begin{array}{c}\text { gubici, } \\
\text { kašnjenje, } \\
\text { prop. } \\
\text { opseg }\end{array}$ & $\begin{array}{c}\text { gubici, } \\
\text { kašnjenje, } \\
\text { prop. } \\
\text { opseg }\end{array}$ & $\begin{array}{c}\text { gubici, } \\
\text { kašnjenje, } \\
\text { prop. opseg }\end{array}$ & nema & $\begin{array}{c}\text { gubici, } \\
\text { propusni } \\
\text { opseg }\end{array}$ \\
\hline $\begin{array}{c}\text { AAL } \\
\text { protokoli }\end{array}$ & AAL-1 & AAL-2 & $\begin{array}{c}\text { AAL-3/4 } \\
\text { ili AAL-5 }\end{array}$ & $\begin{array}{c}\text { AAL-3/4 } \\
\text { ili AAL-5 }\end{array}$ & $\begin{array}{c}\text { AAL-3/4 } \\
\text { ili AAL-5 }\end{array}$ \\
\hline
\end{tabular}

U tabeli 2 prikazane su različite klase usluga sa različitim zahtevima $u$ pogledu QoS-a. Svaka od klasa usluga podržava određene aplikacije koje nose određene zahteve za kvalitet. Aplikacioni QoS zahtevi preslikavaju se na parametre kvaliteta koji moraju biti vidljivi i registrovani kao veličine sa kvantitativnim vrednostima, koje se mogu podešavati $u$ određenim granicama.

Klasa $C B R$ podržava aplikacije koje se obavljaju u realnom vremenu i imaju stoga ograničenja u pogledu kašnjenja i varijacije kašnjenja. Primeri za ovakve aplikacije su prenos govornih signala i emulacija kanala za prenos multipleksnih E1/T1 signala.

Parametri kvaliteta usluga su: kašnjenje ćelije u prenosu (CTD - Cell Transfer Delay), varijacija kašnjenja ćelija (CVD - Cell Variation Delay) i verovatnoća gubitka ćelija (Cell Loss Rate).

Za usluge klase CBR koriste se mehanizmi koje poseduje protokol AAL-1 za obezbeđenje parametara kvaliteta. On omogućava prenos signala sa konstantnom bitskom brzinom i isporuku signala na odredište istom bitskom brzinom. Da bi protokol AAL-1 omogućio pomenute kao što su: segmentacija i reasembliranje, postupci sa varijacijom kašnjenja i ubačenim ćelijama, ekstrakcija digitskog takta $u$ prijemniku i obrada pogrešnih bita.

Protokol AAL-1 ima i druge funkcionalne performanse. Da bi obezbedio zadovoljavajuću vrednost parametara kvaliteta CTD, protokol AAL-1 poseduje funkcionalnu mogućnost koja je poznata kao struktuirani transfer podataka (STD). STD pruža mogućnost da se dolazni niz bita iz predajnika smešta u SAR PDU (Protocol Data Unit) pejlod i otprema bez čekanja da se kompletna ćelija popuni bitima. Na ovaj način stvorena je mogućnost rešavanja problema kašnjenja pri prenosu paketizovanih govornih signala.

Varijacija kašnjenja ćelija (CVD) rešava se korišćenjem bafera u prijemniku. SAR PDU pejlod skladišti se u baferu koji se stalno puni novim podacima. Pejlodi pristižu sa malom varijacijom bitske brzine. Bafer prijemnika prazni se konstantnom brzinom. Kada se isprazni AAL-1 CS mora ubacivati prazne bite, a CS mora prekidati ulaz ćelija u bafer u slučaju kada je prepunjen. U tom slučaju AAL-1 omogućava primenu dve metode koje prijemniku obezbeđuju informaciju o veličini kašnjenja, a to su metoda sinhrone rezidentne vremenske markice (SRTS) i metoda adaptivnog takta.

Svi ATM protokoli, izuzimajući AAL5, sadrže brojač sekvence ćelija, čija je svrha da se na osnovu sadržaja brojača u prijemniku detektuje greška, odnosno gubitak ćelije. AAL-1 protokol poseduje mehanizme za korekciju pojedinačnih grešaka i otkrivanje višestrukih bitskih grešaka.

Klasa VBR ima dve potklase: RT VBR (Real-Time VBR), koja se realizuje u realnom vremenu, i NRT VBR (Non- 
Real Time VBR), tj. VBR koji se ne odvija $u$ realnom vremenu.

RT VBR je namenjen za aplikacije koje imaju stroga ograničenja u kašnjenju signala, kao što je to slučaj sa video uslugama.

QoS parametri za RT VBR su maksimalno kašnjenje ćelija u prenosu i amplituda varijacije kašnjenja ćelija.

Protokol AAL-2 namenjen je za realizaciju usluge klase $B$, kao što je, na primer, prenos komprimovanih audio i video signala. Ova usluga se odlikuje time što se prenos obavlja po uspostavljenoj vezi promenljivom brzinom, a postoji velika osetljivost na gubitak bitske sinhronizacije.

Zbog primenjene kompresije izvor konstantne bitske brzine postaje varijabilan, a trenutna bitska brzina zavisi od stepena kompresije signala. Na primer, ako je stepen kompresije video signala 10:1, generiše se samo $10 \%$ bita u odnosu na broj bita bez kompresije. Zato se ne mogu u potpunosti puniti SAR PDU pejlodi. Da bi se izbeglo kašnjenje zbog čekanja i potpuno napunili SAR PDU pejlodi, protokol AAL-2 mora biti opremljen mehanizmima za delimično popunjavanje polja SAR PDU. Zbog toga AAL-2 SAR PDU protokol poseduje polje L1 koje predstavlja indikator dužine. Polje L1 namenjeno je za označavanje parcijalne zauzetosti korisničkog polja ćelije, a na taj način izbegava se unošenje kašnjenja.

NRT VBR namenjen je za aplikacije koje su mnogo manje osetljive na varijaciju kašnjenja kroz mrežu. Među takve aplikacije spada usluga prenosa podataka (prenos datoteka).

QoS parametri za NRT VBR usluge su: srednja vrednost bitskog protoka, CTD - kašnjenje u prenosu ćelija i CLR - verovatnoća gubitka ćelija.
Prenos podataka je, po svojoj prirodi, osetljiv na greške, a poseduje osobinu naletnosti. $\mathrm{Za}$ prenos podataka preko ATM mreže koriste se protokoli AAL-3/4 i AAL-5. Protokol AAL-3/4 podržava prenos podataka sa promenljivom dužinom blokova koji se pri otpremi moraju segmentirati na ćelije, a u prijemu reasemblirati u izvorni oblik. Ovaj protokol ima mogućnost da u komunikaciji podrži više korisnika istovremeno. Protokol AAL-3/4 poseduje polje MID (identifikator multipleksa) koje omogućava multipleksiranje više istovremenih segmenata PDU pejloda - jednim AAL-3/4.

Svaki PDU promenljive dužine $u$ AAL predajniku obeležava se sadržajima polja MID. PDU pejlodi se $u$ isto vreme segmentiraju, kako bi se izbeglo neprihvatljivo kašnjenje nekog od pejloda koji se multipleksiraju. Korišćenjem polja MID PDU pejlodi se učešljavaju, čime se obezbeđuje njihov efikasan prenos.

Klasa $A B R$ je relativno nova i specifična za ATM mreže. Ona podržava aplikacije koje mogu da podnesu promenu bitskog protoka bez nepovoljnog uticaja na funkcionalnost date aplikacije. Ovakav postupak prenosa obezbeđuje „best effort“ kvalitet usluge, koji obezbeđuju IP mreže.

QoS parametar za klasu ABR je verovatnoća gubitka ćelije. Za realizaciju ove klase usluga preko ATM mreže koriste se protokoli AAL-3/4 i AAL-5.

Klasa UBR je usluga slična ABR, ali je prenos ovom klasom manje pouzdan. Namenjena je za aplikacije koje su veoma tolerantne po pitanju kašnjenja, a ne izvršavaju se u realnom vremenu. Klasa UBR nema nikakvih garancija za kvalitet usluga. Za realizaciju ove klase usluga, preko ATM mreže, koriste se protokoli AAL-3/4 i AAL-5. 


\section{Preslikavanje QoS parametara na ATM mrežne performanse}

Preslikavanje QoS parametara jedan je od bitnih elemenata u koncepciji širokopojasnih mreža [1]. Najpre se preslikavanje izvodi između korisničkog QoS-a i aplikacionog QoS-a. Zatim se aplikacioni QoS preslikava na QoS prenosa i komutacije, odnosno ATM protokole i konačno se preslikava (mapira) na ATM mrežne performanse.
Preslikavanjem QoS parametara na ATM mrežne performanse obezbeđuje se garantovani kvalitet usluga s kraja na kraj veze u ATM mreži. Garantovani kvalitet, u zavisnosti od tipa usluge, obezbeđuju ATM protokoli.

U tabeli 3 prikazani su različiti uzroci degradacije QoS-a, i metode koje omogućavaju da se sa komunikacionim protokolima na različitim slojevima otklone uzroci narušavanja kvaliteta usluga.

Tabela 3

Uzroci degradacije kvaliteta i metode otklanjanja uzroka

\begin{tabular}{|c|c|c|c|c|c|}
\hline $\begin{array}{l}\text { Komunikac. } \\
\text { protokoli }\end{array}$ & \multicolumn{5}{|c|}{ Uzroci degradacije i metode poboljšanja kvaliteta } \\
\hline $\begin{array}{c}\text { Protokoli viših } \\
\text { slojeva }\end{array}$ & $\begin{array}{l}\text { korekcija grešaka; } \\
\text { retransmisija }\end{array}$ & $\begin{array}{c}\text { slojevito } \\
\text { kodovanje poruka }\end{array}$ & & $\begin{array}{l}\text { kašnjenje pri } \\
\text { kodovanju }\end{array}$ & džiter kodovanja \\
\hline AAL protokoli & & $\begin{array}{c}\text { prepunjavanje } \\
\text { bafera; } \\
\text { odbacivanje } \\
\text { zakas. ćelija; } \\
\text { ubacivanje } \\
\text { praznih ćelija }\end{array}$ & $\begin{array}{l}\text { odbacivanje } \\
\text { ubačenih ćelija }\end{array}$ & $\begin{array}{l}\text { kašnjenje kod } \\
\text { asembliranja i } \\
\text { otpreme }\end{array}$ & $\begin{array}{c}\text { džiter pri otpremi } \\
\text { džiter pri } \\
\text { asembliranju } \\
\text { ćelija }\end{array}$ \\
\hline ATM sloj & & $\begin{array}{c}\text { prepunjavanje } \\
\text { bafera }\end{array}$ & & $\begin{array}{c}\text { kašnjenje zbog } \\
\text { čekanja u } \\
\text { redovima }\end{array}$ & $\begin{array}{l}\text { džiter zbog } \\
\text { čekanja u } \\
\text { redovima }\end{array}$ \\
\hline Fizički sloj & $\begin{array}{l}\text { bitske greške (u } \\
\text { pejlodu) }\end{array}$ & $\begin{array}{c}\text { bitske greške u } \\
\text { zaglavlju; } \\
\text { korekcija grešaka }\end{array}$ & $\begin{array}{c}\text { odbacivanje ćelija } \\
\text { sa greškama }\end{array}$ & $\begin{array}{c}\text { kašnjenje } \\
\text { prilikom } \\
\text { propagacije }\end{array}$ & $\begin{array}{l}\text { džiter u pristupu } \\
\text { na UNI interfejsu }\end{array}$ \\
\hline Tip otkaza & pogrešna ćelija & izgubljena ćelija & ubačena ćelija & kašnjenje ćelija & džiter ćelija \\
\hline
\end{tabular}

Aplikacioni podsistem obezbeđuje funkcije kao što su: upravljanje multimedijalnim pozivom i posluživanje poziva, sinhronizacija medija, upravljanje izlazno-ulaznim modulima i obrada aplikacija.

Prenosni i komutacioni podsistem obezbeđuje upravljanje vezom, upravljanje propusnim opsegom i bitskim protokom. Prenosni i komutacioni podsistemi čine mrežu i određuju ATM mrežne performanse, a uključuju protokol ATM sloja i ATM adaptacione slojeve, odnosno AAL protokole.
S vrha do dna arhitekture ATM protokola raspodeljene su funkcije kojima se obezbeđuje zahtevani QoS, odnosno otklanjaju uzroci koji su izazvali degradaciju kvaliteta usluga.

QoS parametri podržani AAL protokolima i njihove granične vrednosti

QoS parametri AAL-a predstavljaju QoS zahteve koji su potrebni višim nivoima protokola, odnosno uslugama koje ti protokoli podržavaju pri komunikaciji preko ATM mreže. To znači da se QoS 
parametri protokola razlikuju prema vrsti usluge koju podržavaju. QoS zahtevi predstavljaju se kao granične vrednosti QoS parametara AAL-a. Zadatak AAL-a jeste da obezbedi odgovarajući traženi QoS za svaku vrstu usluge. Time će se eliminisati razlika između QoS AAL-a i QoS ATM sloja, odnosno protokola.

Konvergentni podsloj (Convergences Sublayer - CS) ATM adaptacionog sloja (AAL protokoli) podeljen je na dva podsloja, i to: konvergentni podsloj specifične usluge (Service Specific Convergence Sublayer) SS CS i zajednički deo konvergentnog podsloja (Common Part Convergence Sublayer) CP CS.

Svaki od SS CS, odnosno CP CS usmerava se prema određenom ATM adaptacionom sloju, odnosno AAL protokolu, kako je to prikazano na slici 2.

Sloj AAL protokola podeljen je na dva podsloja, i to na: podsloj segmentacije i reasembliranja - SAR i konvergentni podsloj-CS.

Podsloj CS zavisi od vrste usluge, a omogućava AAL uslugu korišćenjem AAL SAR protokola. Treba imati u vidu da poruka od viših slojeva (govor, video signal, podaci, multimedijalna poruka, bitski niz E1/T1 signala, itd.) dolazi u formatu određenog rama (frame), koji se segmentira u smeru predaje signala preko ATM mreže, a reasemblira u smeru prijema signala od ATM mreže (slika 3). Na taj način omogućava se prenos SAR segmenata protokolom jedinice podataka (Protocol Data Unit - PDU). Jedinica podataka DU smeštena je u pejlod ATM ćelije. U zavisnosti od tipa usluge, DU ima određenu dužinu izraženu brojem bajtova koji ne može biti veći od 48 .

S obzirom na to da se QoS zahtevi predstavljaju kao granične vrednosti QoS parametara AAL-a, važno je da se odrede granične vrednosti AAL QoS parametara. U principu, QoS parametri AAL-a mogu se razlikovati prema vrsti usluge koju podržavaju.

Definisanje opštih QoS parametara AAL-a

Ovi parametri kvantitativno se mogu standardizovati ili definisati za konkretnu vrstu usluge.

Granična vrednost verovatnoće pogrešnih ramova (Frame Error Ratio FER-Bound). Ram korisničke poruke

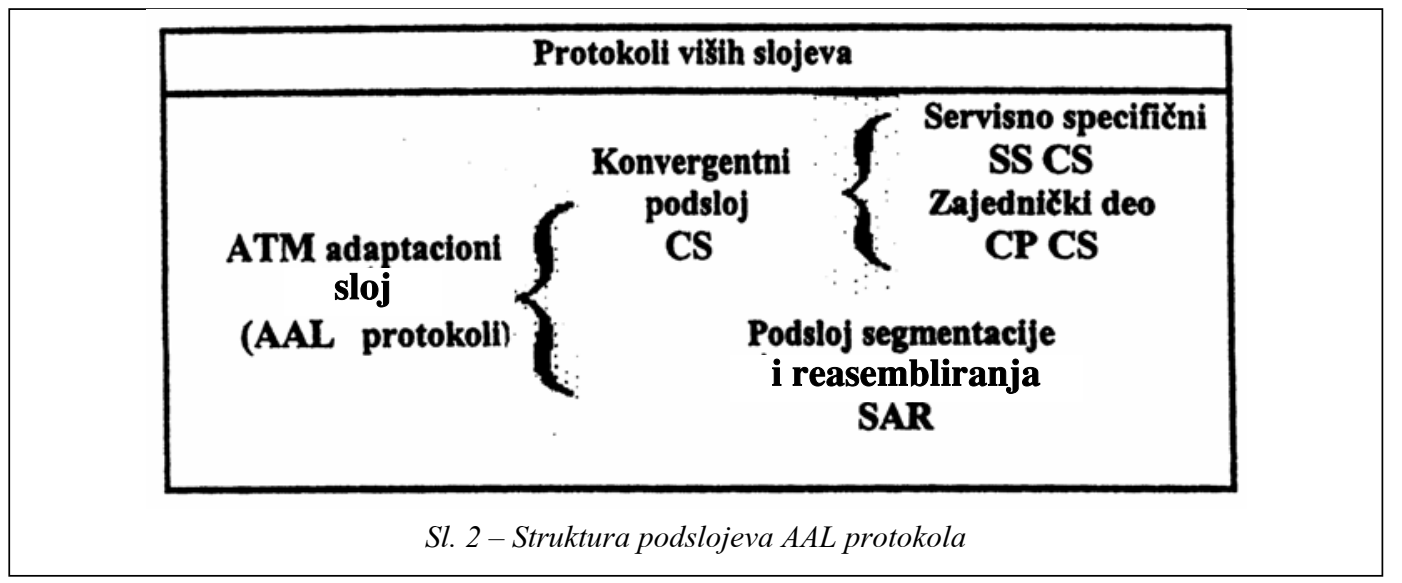




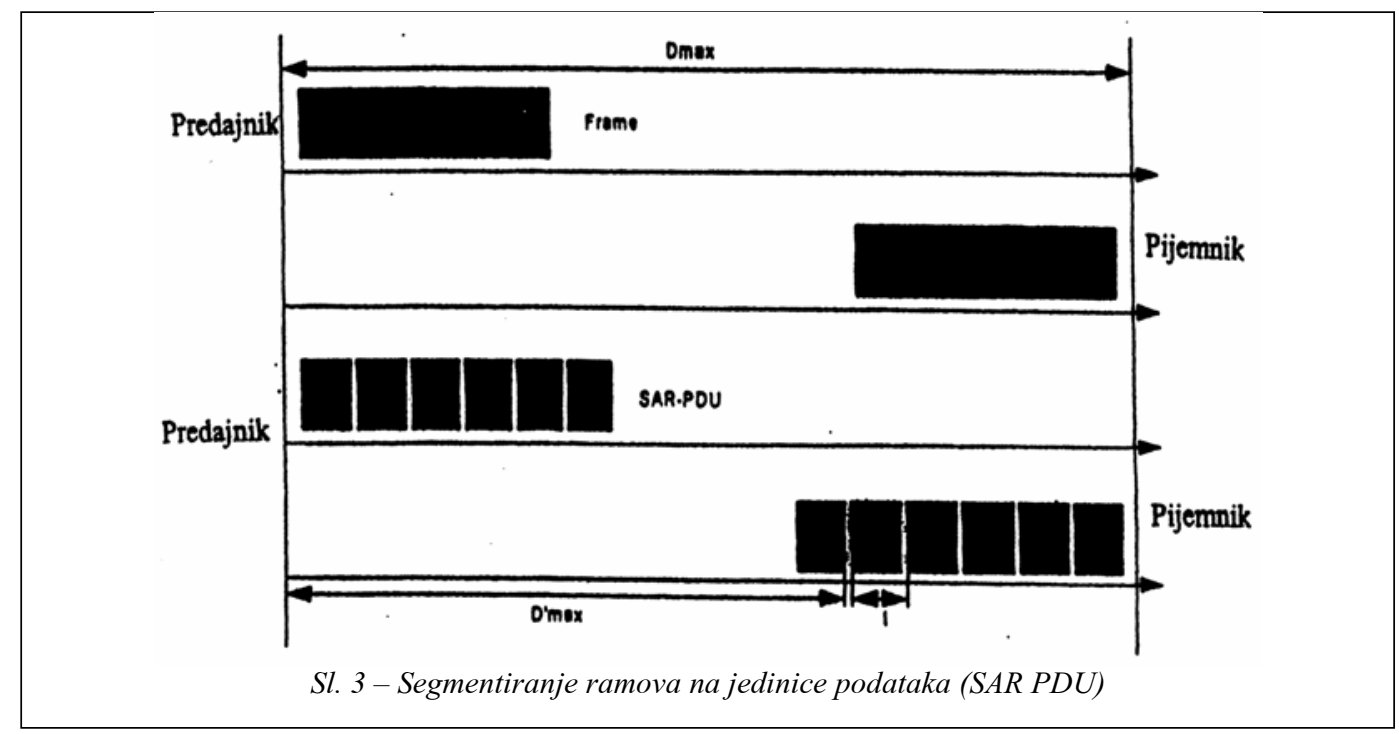

predstavlja SDU koji je primljen od protokola višeg sloja. FER se definiše kao odnos broja ramova sa greškama Rg prema zbiru broja primljenih ramova bez grešaka Ri i broja ramova sa greškama:

$$
F E R=R g /(R g+R i)
$$

Granična vrednost FERmax definiše se izrazom:

\section{FER $\leq$ FERmax}

gde je:

FER - verovatnoća pogrešnih ramova podržana AAL-om,

FERmax - granična vrednost verovatnoće pogrešnih ramova određena protokolom višeg sloja.

U ovom slučaju koristi se FER, tj. verovatnoća pogrešnih ramova umesto verovatnoće pogrešnih bita BER (Bit Error Rate) zbog toga što protokol svakog sloja upravlja svojim SDU, a QoS parametri moraju biti bazirani na jedinici podataka usluge, a ne na verovatnoći bitske greške.

PDU SAR predstavlja ram čija je dužina mnogo veća od veličine SAR
PDU, kako je to prikazano na slici 2. U procesu preslikavanja QoS parametara posmatra se SAR PDU, pa se prema tome FER odnosi na SAR ram.

Korišćenje FER može biti problematično u slučaju usluga prenosa video signala i govora, kod kojih pojava rama sa greškom može dovesti do gubitka sinhronizacije, a time i do mogućnosti ozbiljne degradacije kvaliteta video signala ili multimedijalne poruke. To se ne odnosi na slučaj kada se koristi tehnika slojevitog kodovanja video signala, kod koje se svaka komponenta video signala može prenositi odvojeno sa sopstvenim QoS zahtevima. U tom slučaju komponente signala koje sadrže informacije o sinhronizaciji mogu biti prenošene sa strožim QoS-om u odnosu na druge video signale.

Minimalna granična vrednost propusnog opsega (Troughput Bound Wmin) date veze predstavlja vrednost bitske brzine koja se sigurno može ostvariti datom vezom, a definiše se relacijom:

$$
W \geq W \min
$$


gde je:

$\mathrm{W}$ - propusni opseg obezbeđen AAL-om, Wmin - granična vrednost propusnog, određena protokolom višeg sloja.

Protokol AAL mora obezbediti Wmin višem sloju, sve vreme trajanja veze. Postoji više razloga za preslikavanje zahteva za propusni opseg. Propusni opseg koji se zahteva od korisnika usluge ne uzima u obzir premašenja koja mogu nastati zbog upravljačkih informacija, a koje zahteva skup protokola po pojedinim nivoima. Retransmisija kod prenosa podataka smanjuje efektivni propusni opseg, a zahtevani propusni opseg može biti znatno smanjen tehnikama kompresije govornih i video signala.

Granična vrednost kašnjenja ramo$v a$ (Frame Delay Bound - Dmax) definiše se relacijom:

$$
D i \leq \text { Dmax, za svako } i
$$

gde je:

Di - kašnjenje sa kojim je i-ti ram otpremljen od višeg nivoa i isporučen na odredište,

Dmax - najveća granična vrednost kašnjenja.

Granična vrednost varijacije $k a-$ šnjenja ramova (Frame Delay Variation Bound - Jmax) definiše se relacijom:

$$
J i=D i-D \leq J m a x, \text { za svako } i
$$

gde je:

D - idealno ili ciljno kašnjenje dobijeno pomoću AAL protokola,

$\mathrm{Ji}$ - džiter i-tog rama otpremljenog od višeg nivoa $i$ isporučenog na odredište, Jmax - najveća granična vrednost džitera.
QoS parametri podržani ATM

slojem i njihove granične vrednosti

Na ATM sloju definišu se sledeći QoS parametri i njihove granične vrednosti:

- granična vrednost verovatnoće gubitka ćelija (Cell Loss Ratio Bound CLRmax) specifičan je parametar ATM-a, a nastaje kao rezultat prepunjavanja bafera u ATM komutacionim sistemima. Prepunjavanje se javlja usled nagomilavanja saobraćaja;

- granična vrednost propusnog opsega (Throughput Bound - W'min). Zahtevi za propusni opseg definišu se preko Wmin parametra. U ATM sloju granična vrednost propusnog opsega definiše se kao minimalna širina propusnog opsega za datu vezu;

- granična vrednost kašnjenja i džitera (Cell Delay and Jitter Bound D'max, J'max) u ATM sloju ima istu definiciju kao u AAL-u, uzimajući u obzir da se ove vrednosti odnose na ćelije, a ne na ramove;

- granična vrednost verovatnoće ubacivanja ćelija (Cell Insertion Rate Bound - CIR). Ubacivanje ćelija nastaje kao posledica grešaka koje nastaju u zaglavlju ATM ćelije. ATM komutacioni sistemi otkrivaju i odbacuju ćelije koje imaju grešku u zaglavlju, a ALL protokoli svojim funkcijama takođe otkrivaju greške u zaglavlju. CIR se obično ne tretira kao QoS parametar, zbog toga što je neznatan $\mathrm{u}$ poređenju sa CLR, tj. verovatnoćom gubitka ćelija.

\section{Preslikavanje QoS parametara sa SAR podsloja na ATM sloj}

AAL je podeljen na SAR podsloj i konvergentni podsloj (CS). Konvergentni 
podsloj zavisi od vrste usluge i omogućava AAL uslugu u AAL SAR. Da bi se dobili uopšteni rezultati vezani za preslikavanje nezavisno od tipa AAL protokola, pretpostaviće se da AAL ne koristi CS, već ima SAR PDU. To je struktura kao kod AAL-1 protokola.

Preslikavanjem se formiraju granične vrednosti mrežnih parametara (NP) CLRmax, W'min, D'max, J'max, korišćenjem graničnih vrednosti AAL QoS parametara - FERmax, Wmax, Dmax i Jmax. NP parametri su, u suštini, parametri ATM sloja.

Granična vrednost verovatnoće gubitka ćelija CLRmax data je sledećom relacijom:

$C L R(S A R)=C L R(A M T)=C L R($ prema šenja)

gde je:

CLR (SAR) - CLR od SAR podsloja,

CLR (ATM) - CLR na ATM sloju,

CLR (premašenje) - verovatnoća gubitka ćelije prouzrokovana prepunjavanjem bafera.

Verovatnoća pojave rama sa greškom na SAR podsloju izračunava se iz sledeće relacije:

$$
\begin{aligned}
& \text { FER }=\sum_{M} P(\text { pogrě̌an ram } M=m) \\
& P(M=m) \\
& =\sum_{M}\left[1-\left(1-p_{e}\right)^{m}\right] P(M=m) \\
& =\sum_{M} m p_{e} P(M=m),
\end{aligned}
$$

(uz pretpostavku da je $p_{e} \ll 1$ $=p_{e} \sum_{M} m P(M=m)=p_{e} E$

gde je:

$p_{e}-$ verovatnoća pojave greške SAR PDU na SAR podsloju,

$M$ - slučajna promenljiva koja označava broj SAR PDU u jednom ramu,

$P(M=m)$ - verovatnoća pogrešnog rama, $E$ - dužina rama.

Verovatnoća greške SAR PDU nije direktno povezana sa CLR (SAR) zbog toga što se mora uzeti u obzir bilo koji mehanizam zamene SAR PDU. Tako, na primer, ako su detektovane izgubljene ćelije i zamenjene praznim ćelijama da bi se sačuvala celina broja bita, time se, takođe, unose greške u pejlodu. Zbog toga se CLR (SAR) mora uzeti sa određenim faktorom korekcije. Imajući to u vidu, verovatnoća greške SAR PDU izračunava se iz sledeće relacije:

$p_{e}=C L R(S A R)+\alpha C L R(S A R)$

gde je $1<\alpha<376$ korekcioni faktor koji zavisi od mehanizama zamene izgubljene ćelije. U slučaju video usluga $\alpha$ može da zavisi od primenjene tehnike kodovanja, odnosno kompresije video signala. U slučaju kada nema zamene uzima se da je $\alpha=376$.

CLR (premašenje), koje mora garantovati ATM mreža, može se izračunati iz sledeće relacije:

$C L R \max =C L R($ premašenje $)=p_{e} / \alpha-$ $376 / \alpha B E R$

Granična vrednost propusnog opsega W'min određuje se iz relacije:

$W^{\prime} \min =35 / 47 \mathrm{~W} \min$ 
Ova relacija odnosi se na protokol AAL-1 i prenos E1/T1 signala primarnog multipleksa. Ako se koristi SDH prenos, granična vrednost propusnog opsega mora biti povećana zbog premašenja koje unosi SDH ram.

Granične vrednosti kašnjenja ćelije $i$ džitera D'max i J'max moraju biti garantovane ATM slojem, odnosno protokolom. S druge strane, pomenute veličine zavise od veličine prijemnog bafera prijemnika entiteta AAL-a (tzv. playout bafer). Ugovorene granične vrednosti AAL-ovim entitetima na postojećoj vezi mogu kasnije biti promenjene u strože granične vrednosti kašnjenja i manje stroge granične vrednosti džitera.

Granična vrednost kašnjenja D'max u ATM sloju uslovljena je procesom formiranja SAR podsloja (slika 1), a određuje se iz relacije:

$D^{\prime} \max =\operatorname{Dmax}-\mathrm{I}(M-1)-d \max ($ playout $)$

gde je:

I - interval između SAR PDU-ova, kada je ram podeljen na PDU-ove,

$\mathrm{M}$ - broj PDU-ova u jednom ramu, dmax (playout) - maksimalno kašnjenje u playout baferu.

Granična vrednost za ATM NP (kašnjenje zbog obrazovanja redova čekanja) data je sledećom relacijom:

$D^{\prime} \max (N P)=D^{\prime} \max -D p$

gde je Dp pokazatelj kašnjenja, uključujući kašnjenje propagacije, procesiranja, itd.

Granična vrednost džitera na ATM sloju J'max nije uslovljena procesom SAR podsloja, što znači da se može odrediti iz izraza:
$J^{\prime} \max =J \max +\operatorname{Jmin}($ playout $)$

gde je Jmin (playout) minimalna vrednost džitera nastala zbog kašnjenja $u$ playout baferu.

Granična vrednost džitera za ATM NP (džiter zbog obrazovanja redova čekanja) izračunava se iz relacije:

$J^{\prime} \max =J \max +J \min (U N I)$

gde je sa Jmin (UNI) označen maksimalni džiter ATM ćelija na interfejsu korisnika mreža (User Network Interface - UNI).

Postavlja se pitanje - kako se podržavaju parametri kvaliteta usluga koji su preslikani na ATM protokole. Rešenje se nalazi u kontroli i upravljanju saobraćajem, merama kao što su:

- upravljanje pristupom mreži (Convenction Admission Control - CAC);

- oblikovanje saobraćaja (Traffic Shaping - TS);

- posluživanje saobraćaja (Traffic Policing - TP);

- kontrola zagušenja (Congestion

Control - CC).

CAC funkcija odnosi se na odluku o tome da li dozvoliti formiranje traženih VPI/VCI sa zahtevanim protocima, u zavisnosti od toga da li mreža može da zadovolji QoS sa zahtevanom klasom usluga, a da se pri tome ne ugrozi QoS postojećih veza.

TS obavlja funkcije interfejsa korisnik - ATM mreža (UNI). Saobraćaj se oblikuje tako da odgovara parametrima dogovorenim $\mathrm{u}$ trenutku uspostavljanja veza, odnosno u skladu sa algoritmima za brzinu generisanja ćelija (Genetic Cell Rate Algorittam).

TP na ulazu u komutacioni čvor proverava da li se protok ćelija nalazi u 
dogovorenim granicama. ATM komutacioni čvor ima dve mogućnosti: da odbaci ćelije koje se na ulazu ne mogu proslediti ili da njihov prioritet postavi (CLP $=1)$ na visok nivo.

CC funkcije obavljaju ATM komutacioni čvorovi unutar mreže sa ciljem da se izbegne zagušenje saobraćaja. CC metoda zasniva se na uvođenju povratne sprege kojom se ćelije sa izlaza vraćaju na ulaz komutacionog polja.

\section{Zaključak}

$\mathrm{U}$ radu je analizirano preslikavanje parametara kvaliteta usluga na ATM adaptacione protokole, kao i preslikavanje parametara kvaliteta na ATM mrežne performanse. Pomoću protokola adaptacionog sloja ATM mreže obezbeđuje se realizacija različitih klasa usluga. Pokazano je da preslikavanje QoS-a omogućava garantovani kvalitet usluga $\mathrm{s}$ kraja na kraj veze u ATM, odnosno B-ISDN mreži.

Literatura:

[1] Jevtović, M.: Multimedijalne telekomunikacije; ISBN 86903281-6-4; Grafo-Žig, Beograd, 2004.

[2] Jevtović, M.: Kvalitet usluga telekomunikacionih mreža, ISBN 86-903281-1-4; Grafo-Žig, Beograd, 2002.

[3] Jevtović, M.: Telekomunikacione ATM mreže, Grafo-Žig, Beograd, 2001.

[4] Standardi Međunarodne unije za telekomunikacije, preporuke ITU-T za širokopojasne mreže (B-ISDN). 
Uzroci degradacije kvaliteta i metode otklanjanja uzroka

\begin{tabular}{|c|c|c|c|c|c|}
\hline $\begin{array}{l}\text { Komunikac. } \\
\text { protokoli }\end{array}$ & \multicolumn{5}{|c|}{ Uzroci degradacije i metode poboljšanja kvaliteta } \\
\hline $\begin{array}{c}\text { Protokoli viših } \\
\text { slojeva }\end{array}$ & $\begin{array}{c}\text { korekcija grešaka; } \\
\text { retransmisija }\end{array}$ & $\begin{array}{c}\text { slojevito } \\
\text { kodovanje poruka }\end{array}$ & & $\begin{array}{c}\text { kašnjenje pri } \\
\text { kodovanju }\end{array}$ & džiter kodovanja \\
\hline AAL protokoli & & $\begin{array}{c}\text { prepunjavanje } \\
\text { bafera; } \\
\text { odbacivanje } \\
\text { zakas. ćelija; } \\
\text { ubacivanje } \\
\text { praznih ćelija }\end{array}$ & $\begin{array}{c}\text { odbacivanje } \\
\text { ubačenih ćelija }\end{array}$ & $\begin{array}{l}\text { kašnjenje kod } \\
\text { asembliranja i } \\
\text { otpreme }\end{array}$ & $\begin{array}{c}\text { džiter pri } \\
\text { otpremi; } \\
\text { džiter pri } \\
\text { asembliranju } \\
\text { ćelija }\end{array}$ \\
\hline ATM sloj & & $\begin{array}{l}\text { prepunjavanje } \\
\text { bafera }\end{array}$ & & $\begin{array}{l}\text { kašnjenje zbog } \\
\text { čekanja u } \\
\text { redovima }\end{array}$ & $\begin{array}{l}\text { džiter zbog } \\
\text { čekanja u } \\
\text { redovima }\end{array}$ \\
\hline Fizički sloj & $\begin{array}{l}\text { bitske greške (u } \\
\text { pejlodu) }\end{array}$ & $\begin{array}{c}\text { bitske greške u } \\
\text { zaglavlju; } \\
\text { korekcija grešaka }\end{array}$ & $\begin{array}{c}\text { odbacivanje ćelija } \\
\text { sa greškama }\end{array}$ & $\begin{array}{l}\text { kašnjenje } \\
\text { prilikom } \\
\text { propagacije }\end{array}$ & $\begin{array}{l}\text { džiter u pristupu } \\
\text { na UNI interfejsu }\end{array}$ \\
\hline Tip otkaza & pogrešna ćelija & izgubljena ćelija & ubačena ćelija & kašnjenje celija & džiter ćelija \\
\hline
\end{tabular}

Sl. 1 - Arhitektura ATM protokola (AAL sloj):

AAL - ATM adaptacioni sloj (ATM Adaptation Lauer); A, B, C, D-klase usluga definisane ITU-T; , $X “,, Y$ “ - klase usluga pri promenljivoj bitskoj brzini; , N/A “ - klasa usluga koje se odnose na signalizaciju AAL; SVC - komutirani - virtuelni kanali ili komutirana virtuelna kola; SVC class - SVC klase usluga; VBR promenljiva bitska brzina (Variable Bit Rate); SSCS - podsloj specifične usluge (Service Specific Convergence Sublayer); SAR - segmentacija i reasembliranje (Segmentation and Reassembly); TCP/IP protokol upravljanja prenosom/medumrežni protokol (Transmission Control Protocol/Internet); CLNS mrežne usluge (Connection less network services)

\begin{tabular}{|c|c|c|}
\hline \multicolumn{3}{|c|}{ Protokoli visih slojeva } \\
\hline $\begin{array}{c}\text { ATM adaptacioni } \\
\text { \& śloj } \\
\text { (AAL protokoli) }\end{array}$ & $\begin{array}{l}\begin{array}{c}\text { Konvergentni } \\
\text { podsloj } \\
\text { CS }\end{array} \\
\text { Pods } \\
\text { ifr }\end{array}$ & $\begin{array}{l}\text { Servisno specifični } \\
\quad \text { SS CS } \\
\text { Zajednixki deo } \\
\quad \text { CP CS } \\
\text { mentacije } \\
\text { liranja } \\
\text { R }\end{array}$ \\
\hline
\end{tabular}

Sl. 2 - Struktura podslojeva AAL protokola 


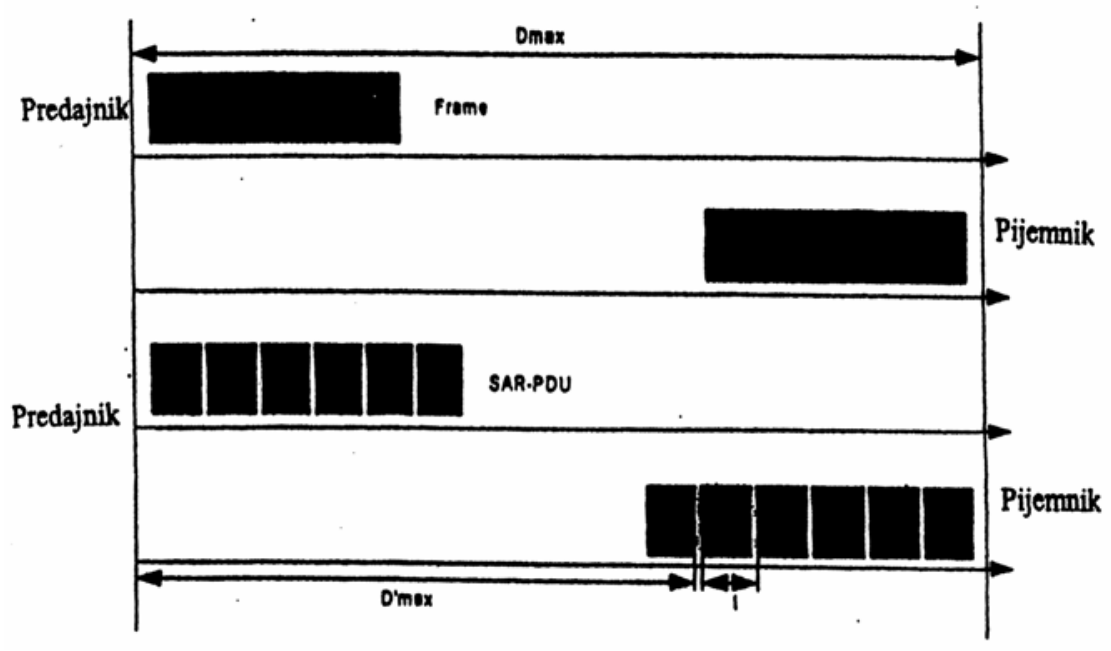

Sl. 3 - Segmentiranje ramova na jedinice podataka (SAR PDU) 